\title{
HAEMOGLOBIN POLYMORPHISM IN WILD AND CULTURED AFRICAN CATFISH (Clarias gariepinus BURCHELL, 1822)
}

\author{
$*^{1}$ Diyaware, M. Y., ${ }^{1}$ Ahmed, A. B., ${ }^{2}$ Akinyemi, A. A. and ${ }^{1}$ Suleiman, S. B. \\ ${ }^{1}$ Department of Fisheries, Faculty of Agriculture, University of Maiduguri, Nigeria \\ ${ }^{2}$ Department of Aquaculture and Fisheries Management, College of Environmental Resources Management, Federal \\ University of Agriculture, Abeokuta, Nigeria \\ *Corresponding Author: mydiyaware@gmail.com, Tel: 08022516926 \\ (Received: 20 ${ }^{\text {th }}$ September, 2016; Accepted: $13^{\text {th }}$ August, 2017)
}

ABSTRACT

\begin{abstract}
Haemoglobin polymorphism, haemoglobin concentration, blood group and genotypes of wild and cultured Clarias gariepinus were investigated. Blood samples of Clarias gariepinus collected from Lake Alau (wild) and Dalori fish farm (cultured) were subjected to cellulose acetate electrophoresis to reveal the activities of hemoglobin $(\mathrm{Hb})$. The result shows that both wild and cultured C. gariepinus had AA, BB and CC genotypes in the males and females. However, BD genotype was observed only in the female wild C. gariepinus. The percentage AA and BB genotypes of wild male C. gariepinus was $6.6 \%$ each. Wild females had AA, BB, CC and BD genotype with frequencies of 26.6, 33.3, 20 and 6.6\% respectively. Cultured male $C$. gariepinus had AA, BB and CC with frequencies of 13.3, 26.6 and $6.6 \%$, respectively, while the female C. gariepinus had AA, BB and CC with frequencies of 20,13.3 and 20\% respectively. Wild C. gariepinus had the highest $(10.36 \mathrm{~g} / \mathrm{dl})$ haemoglobin concentration value while the cultured strain had $8.86 \mathrm{~g} / \mathrm{dl}$. The blood groups of wild male C. gariepinus were $\mathrm{O}$ $\left(10 \%\right.$ of the population) and $\mathrm{AB}^{+}\left(10 \%\right.$ of the population). The wild females had $\mathrm{O}, \mathrm{O}^{+}, \mathrm{A}^{+}, \mathrm{B}^{+}$and $\mathrm{AB}^{+}$with 40 , $10,10,10$ and $10 \%$ of the population respectively, Cultured male had $\mathrm{O}^{+}, \mathrm{A}^{+}$and $\mathrm{AB}^{+}(10,20$ and $20 \%$ of the fish observed) respectively. The blood group observed in the cultured female C. gariepinus were $\mathrm{O}^{-}(30 \%), \mathrm{A}^{-}(10 \%)$ and $\mathrm{B}^{+}(10 \%)$. The $\mathrm{BD}$ genotype observed in a wild strain of C. gariepinus indicates incomplete (partial) dominance and rare allele. This could be an indication of natural hybridization.
\end{abstract}

Keywords: Haemoglobin concentration, polymorphism, genotype, blood group, wild and cultured, Clarias

\section{INTRODUCTION}

The African catfish Clarias gariepinus is the most widely cultured catfish in Africa and the third most cultured catfish species in the world (Garibaldi, 1996). Its aquacultural attributes include the highest growth rate at high stocking densities under culture condition, high fecundity rate, resistance to diseases, ability to tolerate a wide range of environmental extremes (Fagbuaro, 2014). African catfish provides food for the populace, allows improved protein nutrition because it has a high biological value in terms of high protein retention in the body, higher protein assimilation as compared to other protein sources, low cholesterol content (Anoop et al., 2009). C. gariepinus production is important to the Nigerian economy because it serves as a source of income, reduces the rate of unemployment in the economy and increases the Gross Domestic Product (GDP) (Adebayo and Daramola 2013).

Polymorphism is a genetic variant that appears in at least $1 \%$ of the population. It is a discontinuous genetic variation where two or more forms, stages, or types exist in the same species within the same population, it can apply to biochemical, morphological, and behavioural characteristics, but must be discontinuous (Agaviezor et al., 2013). Polymorphism is genetically useful to help determine the origin, phylogenetic relationships compiled among species and or groups within the species. Most of the blood protein polymorphism was genetically regulated by pair of alleles or sequence of alleles without dominance (Warwick et al. 1990; Abubakar et al.2014).

Haemoglobin polymorphism have been used as marker to study evolutionary relationship in mammals (Chineke et al., 2007). Evolutionary relationship between sheep and goat breeds, deer species and chicken genotype has been examined (Yang and Jiang 2005). According to Chineke et al. (2007), the study of biochemical polymorphism of blood protein is at present a useful tool to characterize livestock breed and fish population, hence it contributes to the knowledge of genetic 
similarity and distance (Omitogun 2004). According to Fisher (1980), information on polymorphism of fish species can be used to enhance its capability to adapt to changing environment which is necessary for survival of the species. Polymorphism also increases adaptability thereby providing for the possibility of genetic change.

Biochemical diversity or polymorphism is the occurrence of varieties attributed to biochemical differences which are under genetic control (Egena and Alao 2014). It has created a leeway for the genetic improvement of farm animals. This is because it can be used as a useful tool for the characterization of livestock breeds and fish. This way, the degree of similarity or differences within and between species of fish can be ascertained using this simple biochemical diversity. This difference or similarity is an important raw material for genetic improvement of fish.

Blood typing have been applied intensively to study variation in fishes (Sindermann, 1967). According to Sindermann (1967), it has also been determined that, as in humans, the frequency of different blood types vary, depending on the population sampled and the variation is of course an important tool to study intermixing of fish population.

Morphological description and morphometric analyses were the first tools used to define fish species (Pante et al., 1988). But these techniques are polygenic, quantitative or continuous characters and their expression is influenced by environmental conditions (Majolagbe et al., 2012). However, many biochemical and molecular markers technique such as allozyme analysis, types of restriction fragment length polymorphism (RFLP), randomly amplified polymorphic DNA (RAPD), amplified fragment length polymorphism (AFLP), microsatellite typing etc. can reveal better diagnostic genetic variations and are usually free from genotype and environmental interactions (Lombard et al., 2001; Torkpo et al., 2006).

The study of haemoglobin patterns provides a very good means of identifying distinct populations or sub-populations of fish (Sick,
1961). Analysis of haemoglobin patterns may be a valuable tool in taxonomy of different species of fish and their hybrids (Perez and Rylander, 1984). Haemoglobin and haemocrit are related to oxygen binding ability of blood and changes in both values, are related to stress.

Animals with genotype $\mathrm{Hb}$ and $\mathrm{BB}$ have been reported to have better body weight (Arora et al., 1971). In sheep, with $\mathrm{Hb} \mathrm{AB}$ and $\mathrm{Hb} B B$ genotypes had been observed to have an effect on their performance (Dally et al., 1980; Arora, 1984; Dratch et al., 1986). Sick (1965) reported haemoglobin polymorphism in Cod and found that the frequencies of the $\mathrm{Hb} I^{\prime}$ allele range from 55 to $72 \%$. Braman et al. (1980) investigated haemoglobin polymorphism in a population of adult Cutthroat trout (Salmo clarkii) by employing starch gel electrophoresis and reported 12 haemoglobin components in the species. Haemoglobin polymorphism has been reported in cattle by Pal and Mummed (2014), in sheep Tsunoda et al. (2010) and Al-Samarrae et al. (2010), in goat Elmaci (2001) and in poultry (Dimri, 1978). Onyia et al. (2015) documented the blood group and genotype of Clarias gariepinus and $C$. anguillaris. Eighty-three percent $(83 \%)$ of males were $\mathrm{O}+$, while $18 \%$ of the females were $A B+$. Both males and females were reported to have AA genotype for both fish species.

A population is said to be polymorphic when two or more distinctly inherited varieties coexist in the same individual (Das and Deb, 2008; Egena and Alao, 2014). This type of polymorphism is being increasingly used to study genetic differences within and between populations and to estimate genetic divergence (Lee et al., 1995). The study of haemoglobin polymorphism in fish has become imperative, because of its importance in the improvement of farm animals due to the fact that some polymorphic alleles may be linked with traits of economic importance (Egena and Alao, 2014). Arora et al. (1971) reported marginally but not significant better body weight in $\mathrm{Hb} \mathrm{BB}$ type animals.

Morphological parameters have been used in the past to identify fish, but more specific tool is needed for a more concise differentiation as the morphological variations have been documented 
to underestimate the true levels of genetic variability. Morphological features have been used in many genetic and breeding studies to identify both parental and hybrid stocks, the morphological characters tend to overlap each other due to differences in environment or mixed up in the population during sample collection (Diyaware et al., 2012).

Molecular markers have recently been used to characterize Clariid species, but these tools are expensive and requiring huge upfront work for their development. There is a paucity of information on haemoglobin polymorphism of Clariid fish. The blood group and genotype of Clariids are yet to be exploited. This study, therefore investigated haemoglobin polymorphism, blood group and genotypes of wild and cultured C. gariepinus.

\section{MATERIALS AND METHODS}

\section{Study Area}

Fish samples from the wild were collected from Lake Alau in Konduga Local Government Area of Borno State, Nigeria, which is located at latitude $11^{\circ}$ and $42^{\prime} 13^{\prime \prime} \mathrm{N}$ and longitude $13016^{\prime}$ 02" E (Google Map, 2017). The study area has two distinct seasons: the dry season, which starts from October to April, while the rainy season commences from July to September.

\section{Experimental Fish}

A total of 15 each of wild and cultured C. gariepinus (330.50 - $900.00 \mathrm{~g}$ weight and 296.90-500.00 mm total length) were procured from fishermen at Lake Alau and fifteen (15) five months old cultured C. gariepinus (463.00 - $700.00 \mathrm{~g}$ weight and $374.50-40.05 \mathrm{~mm}$ total length) were procured from a private fish farm in Maiduguri and were used for the study. All the fish were transported live in 50 litre capacity plastic Jerry-cans half-cut horizontally, to fish hatchery complex of the Department of Fisheries, University of Maiduguri

\section{Sample Collection}

Blood samples were collected from each of the fish samples via the caudal vein according to the method described by Whitman (2004) using separate thermodermic syringes fitted with $2 \mathrm{G}$ needle and emptied into an EDTA bottle containing anticoagulant to prevent the blood from clotting. The labelled blood samples were transferred to the Animal Science laboratory of the University of Maiduguri for determination of haemoglobin concentration, blood group, and cellulose acetate electrophoresis.

\section{Haemoglobin Concentration ( $\mathrm{Hb})$}

The indirect acid haematin (sahli) method LouisBerman (1919) was used. This involved the use of a special haemoglobinometer and a pipette. The graduated tube was filled with $20 \mathrm{ml}$ of $0.1 \mathrm{M} \mathrm{HCl}$ and $0.02 \mathrm{ml}$ of blood sample was added. The mixture was allowed to stand for $5 \mathrm{~min}$ and then a few drops of distilled water were added until the colour matched the standard. Haemoglobin concentration was estimated as follows: $\mathrm{Hbc}=$ coloured matching values $\times 17.2 \mathrm{~g} / 100 \mathrm{~mL} \div 100$ (Cook, 1985; Balasubramaniam and Malathi, 1992)

\section{Determination of Fish Blood Group}

Blood group was determined using a standard test tube agglutination techniques described by Prasad (2013). The blood was dropped on a clean white porcelain tile (Prasad, 2013) using syringe in three different places, then on each of the blood samples, anti-sera A, B and D was dropped, respectively and mixed. The tile was rocked for about 3-5 min. Blood groups were recorded based on the coagulation of blood according to Daramandy and Davenport (1985) and Svobodovaet al. (1991).

\section{Cellulose Acetate Electrophoresis}

Haemoglobin typing was accomplished using cellulose acetate electrophoresis. The cellulose acetate strips were soaked in EDTA borate buffer of $\mathrm{pH} 8.6$ and blotted slightly with filter paper to remove excess buffer. The samples were placed on the cellulose acetate paper and then placed into the electrophoresis tank. The samples were then allowed to separate for about 10-15 minutes. After the separation, the cellulose acetate papers were blotted dry using filter paper and then dried in open air for some minutes and then the numbers of bands were taken. The direct gene counting method was used to score the resulting haemoglobin bands after electrophoresis.

The haemoglobin polymorphism was pointed out by detection of three migration zones as described 
by Agaviezor et al. (2013): a single faster band was designated as the AA homozygote; the presence of a single slower band was designated as BB homozygote and the presence of both bands designated $\mathrm{AB}$ heterozygote. Genotype frequency was estimated according to Agaviezor et al. (2013) formulae as follows:

Gene frequency $\mathrm{AA}=$ No. of $\mathrm{AA} \div$ No. of samples $\times 100 \div 1$

Gene frequency $\mathrm{AB}=$ No. of $\mathrm{AB} \div$ No. of samples $\times 100 \div 1$

Gene frequency $\mathrm{BB}=$ No. of $\mathrm{BB} \div$ No. of samples $\times 100 \div 1$

CC frequency $=$ No. of $\mathrm{CC} \div$ No. of samples $\mathrm{x}$ $100 \div 1$

$\mathrm{BD}$ frequency $=$ No. of $\mathrm{BD} \div$ No. of samples $\mathrm{x}$ $100 \div 1$

\section{Estimation of Gene Frequency}

Gene expression frequencies were estimated using Hardy Weinberg equation (Oghanje et al., 2015): P $=2 \mathrm{~N}_{\mathrm{AA}}+\mathrm{N}_{\mathrm{AB}} \div 2 \mathrm{~N}$ and $\mathrm{Q}=2 \mathrm{~N}_{\mathrm{BB}}+\mathrm{N}_{\mathrm{AB}} \div 2 \mathrm{~N}$, where, $\mathrm{P}=$ gene frequency of allele $\mathrm{A}, \mathrm{N}=$ Total number of individual sampled, $\mathrm{N}_{\mathrm{AA}}=$ observed genotype number for $\mathrm{AA}, \mathrm{N}_{\mathrm{AB}}=$ observed genotype number for $\mathrm{AB}$ and $\mathrm{N}_{\mathrm{BB}}=$ observed genotype number for $\mathrm{BB}$ and $\mathrm{Q}=$ Gene frequency of allele $B$

\section{Scoring of the Genotype on the Cellulose Acetate Gel Electrophoresis}

The cellulose acetate gel electrophoresis representing genotype at the polymorphic protein were manually scored based on their clarity and designated as A, B, C, D, E, F and G from the bottoms to the top of the gel using a ruler as described by Laloei et al. (2013).

\section{Data Analysis}

The haemoglobin data were analysed using One Way Analysis of Variance (ANOVA). The differences between the means were determined using LSD at $95 \%$ confidence level $(p=0.05)$. The blood group, genotype and gene frequency were analysed using descriptive statistics (percentage).

\section{RESULTS}

\section{Genotypes of Wild and Cultured Clarias gariepinus}

Plate 1 and 2 show the representative of acetate electrophoresis of culture and wild strains of $C$. gariepinus respectively.
AA CC
BB

AB

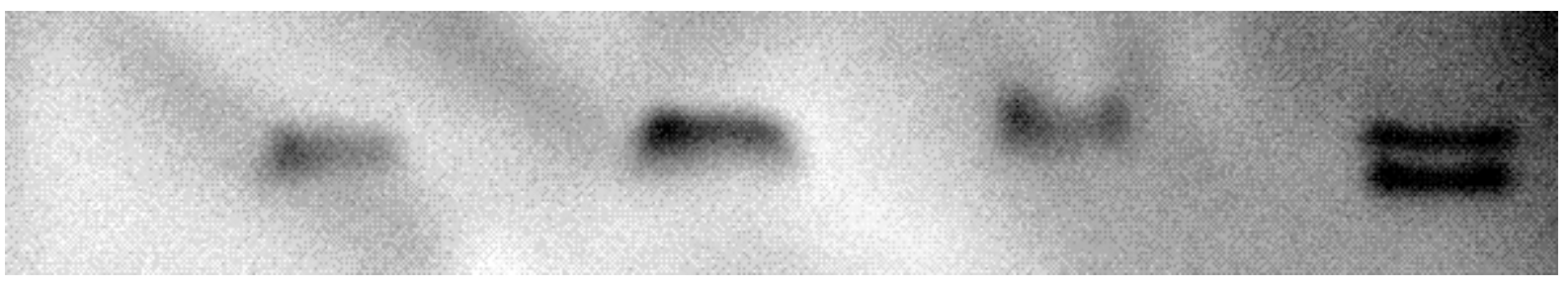

Plate 1: Representative of cellulose acetate electrophoresis gel of cultured Clarias gariepinus

$\mathrm{AB}$

AA

BB

cc

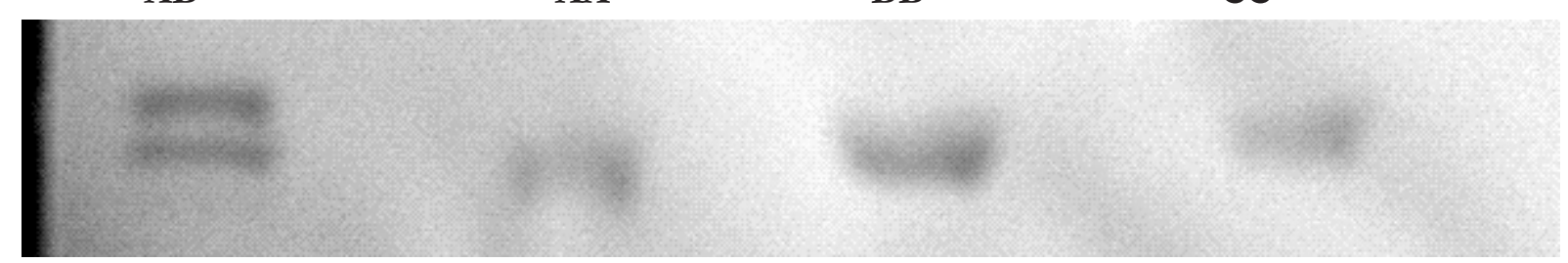

Plate 2: Representative of cellulose acetate electrophoresis gel of wild Clarias gariepinus

Table 1 shows the genotypes of wild (Lake Alau) and cultured Clarias gariepinus in Maiduguri. Both the wild and cultured C. gariepinus had A A, BB and $\mathrm{CC}$ genotypes in the male and females. However, BD genotype was observed only in the female wild C. gariepinus, the percentage $\mathrm{AA}$ and $\mathrm{BB}$ genotypes of wild male C. gariepinus was $6.6 \%$ each. Wild females had AA, BB, CC and BD genotypes with frequencies of 26.6, 33.3, 20 and $6.6 \%$ respectively. Cultured male C. gariepinus had AA, $\mathrm{BB}$ and $\mathrm{CC}$ with frequencies of 13.3, 26.6 and $6.6 \%$ respectively. The female $C$. gariepinus had AA, $\mathrm{BB}$ and $\mathrm{CC}$ with frequencies of $20,13.3$ and $20 \%$ respectively. 
Table 1: Genotypes of wild and cultured Clarias gariepinus

\begin{tabular}{lcccc}
\hline Fish strain & Male & Percentage (\%) & Female & Percentage (\%) \\
\hline Wild C.gariepinus & AA & 6.6 & AA & 26.6 \\
& BB & 6.6 & BB & 33.3 \\
& & & CC & 20 \\
& & & BD & 6.6 \\
\hline Cultured & AA & 13.3 & AA & 20 \\
C.gariepinus & BB & 26.6 & BB & 13.3 \\
& CC & 6.6 & CC & 20 \\
\hline
\end{tabular}

Gene Frequency of Wild and Cultured Clarias gariepinus in Maiduguri

Table 2 shows the gene frequency of the wild and cultured C. gariepinus. Wild strain of C. gariepinus had A, B, C and D alleles, while the cultured strain had allele of $\mathrm{A}, \mathrm{B}$ and $\mathrm{C}$ but had no $\mathrm{D}$ allele. The $\mathrm{A}$, $\mathrm{B}, \mathrm{C}$ and $\mathrm{D}$ alleles of wild C. gariepinus had frequencies of $0.33,0.2,0.1$ and 0.03 respectively. The cultured C. gariepinus allele of A, B and C had frequency of $0.33,0.2$ and 0.13 respectively.

Table 2: Gene frequency of wild and cultured Clarias gariepinus

\begin{tabular}{lccccc}
\hline Fish strain & \multicolumn{3}{c}{ Genotype } & \multicolumn{2}{c}{ Total } \\
\cline { 2 - 5 } & $\mathrm{AA}$ & $\mathrm{BB}$ & $\mathrm{CC}$ & $\mathrm{BD}$ & \\
\hline WCg & 5 & 6 & 3 & 1 & 15 \\
CCg & 5 & 6 & 4 & - & 15 \\
\hline Gene frequency & & & & 0.33 & 0.66 \\
\hline WCg & 0.33 & 0.2 & 0.1 & - & 0.66 \\
CCg & 0.33 & 0.2 & 0.13 &
\end{tabular}

Key: WCg = Wild Clarias gariepinus, $\mathrm{CCg}=$ Cultured C. gariepinus

Genotyping (Allelic) Variation between Wild and Cultured Clarias gariepinus

Table 3 shows genotyping (Allelic) variation within the wild (Lake Alau) and cultured $C$. gariepinus in Maiduguri. The total number of genotypic alleles per population was 15 genotypes and mean of 1.0 per population for each strain

Table 3: Genotyping (Allelic) variation between wild and cultured $C$. gariepinus

\begin{tabular}{llllllllllllllllll}
\hline FS & \multicolumn{1}{c}{ Population number } & \multicolumn{1}{c}{ Total } & Mean \\
& \cline { 2 - 5 } & 2 & 3 & 4 & 5 & 6 & 7 & 8 & 9 & 10 & 11 & 12 & 13 & 14 & 15 & & \\
\hline WCg & 1 & 1 & 1 & 1 & 1 & 1 & 1 & 1 & 1 & 1 & 1 & 1 & 1 & 1 & 1 & 15 & 1.0 \\
$\mathrm{CCg}$ & 1 & 1 & 1 & 1 & 1 & 1 & 1 & 1 & 1 & 1 & 1 & 1 & 1 & 1 & 1 & 15 & 1.0 \\
\hline
\end{tabular}

Key: FS= Fish species, WCg = Wild Clarias gariepinus, $\mathrm{CCg}=$ Cultured C. gariepinus

Haemoglobin Concentrations in Wild and Cultured Clarias gariepinus from Lake Alau

Wild C.gariepinus had significantly $(\mathrm{p}<0.05)$ higher $\mathrm{Hb}$ concentration $(10.36 \mathrm{~g} / \mathrm{dl})$ compared to the cultured C. gariepinus $(8.86 \mathrm{~g} / \mathrm{dl})$. Sex-wise, cultured C. gariepinus males had higher $(10.46 \mathrm{~g} / \mathrm{dl})$
$\mathrm{Hb}$ concentration followed by that of the female CCg with $(10.30 \mathrm{~g} / \mathrm{dl})$. The least $(8.70 \mathrm{~g} / \mathrm{dl}) \mathrm{Hb}$ concentration was observed in the male WCg. No significant variation $(p>0.05)$ was observed sex wise (Table 4). 
Table 4: Mean Haemoglobin Concentrations of Wild and Cultured C. gariepinus

\begin{tabular}{lcc}
\hline Fish Strains & Hb (g/dl) & SEM \\
\hline Wild Clarias gariepinus & $10.36^{\mathrm{a}}$ & 0.36 \\
Cultured Clarias gariepinus & $8.86^{\mathrm{b}}$ & \\
\hline Sex & & 0.74 \\
\hline Wild male Clarias gariepinus & $9.30^{\mathrm{a}}$ & \\
Wild Female Clarias gariepinus & $8.70^{\mathrm{a}}$ & 0.65 \\
Cultured male Clarias gariepinus & $10.46^{\mathrm{a}}$ & \\
Cultured female Clarias gariepinus & $10.30^{\mathrm{a}}$ & \\
\end{tabular}

Mean values in the same column with the same superscripts are not significantly different from each other $(\mathrm{P} \leqslant 0.05)$

Blood Groups of wild (Lake Alau) and blood groups with 40, 10, 10, 10 and 10\% Cultured Clarias gariepinus in Maiduguri

Table 5 shows the blood groups of the two strains of the C. gariepinus. The males of wild C. gariepinus had $\mathrm{O}^{-}$and $\mathrm{AB}^{+}$blood groups with $10 \%$ each, while the females had $\mathrm{O}^{-}, \mathrm{O}^{+}, \mathrm{A}^{+}, \mathrm{B}^{+}$and $\mathrm{AB}^{+}$ respectively. The males of the cultured had $\mathrm{O}^{+}, \mathrm{A}^{+}$ and $\mathrm{AB}^{+}$with 10,20 and $20 \%$ respectively, while the females had $\mathrm{O}^{-} \mathrm{A}^{-}$and $\mathrm{B}^{+}$with 30,10 and $10 \%$ respectively.

Table 5: Blood Groups of Wild and Cultured Clarias gariepinus

\begin{tabular}{lcccc}
\hline Strain & Male group & $\begin{array}{c}\text { Blood group } \\
\mathbf{( \% )}\end{array}$ & $\begin{array}{c}\text { Female blood } \\
\text { group }\end{array}$ & $\begin{array}{c}\text { Blood group } \\
\mathbf{( \% )}\end{array}$ \\
\hline WCg & $\mathrm{O}^{-}$ & 10 & $\mathrm{O}^{-}$ & 40 \\
& $\mathrm{AB}^{+}$ & 10 & $\mathrm{O}^{+}$ & 10 \\
& & & $\mathrm{~A}^{+}$ & 10 \\
& & & $\mathrm{~B}^{+}$ & 10 \\
& & $\mathrm{AB}^{+}$ & 10 \\
\hline Total & $\mathrm{O}^{+}$ & 10 & & 100 \\
\hline CCg & $\mathrm{A}^{+}$ & 20 & $\mathrm{O}^{-}$ & 30 \\
& $\mathrm{AB}^{+}$ & 20 & $\mathrm{~A}^{-}$ & 10 \\
Total & & $\mathrm{B}^{+}$ & 10 \\
\hline
\end{tabular}

Key: $\mathrm{WCg}=$ Wild Clarias gariepinus, $\mathrm{CCg}=$ Cultured Clarias gariepinus

\section{DISCUSSION}

The $\mathrm{O}^{+}$and $\mathrm{AB}^{+}$blood groups recorded in this study for males of wild and cultured species differs from $\left(\mathrm{O}^{-}\right.$and $\left.\mathrm{A}^{+}\right)$for $C$. gariepinus and $C$. anguillaris documented by Onyia et al. (2015). This variation could be due to the differences in the species. The $\mathrm{O}^{+}, \mathrm{A}^{+}$and $\mathrm{AB}^{+}$blood group in male cultured C. gariepinus differs from $\mathrm{O}^{+}$and $\mathrm{AB}^{+}$ recorded by Onyia et al. (2015) for the same fish species. The variation in the blood groups of wild female $C$. gariepinus observed in this study $(\mathrm{O}, \mathrm{A}$ and $\left.\mathrm{B}^{+}\right)$differs from those $\left(\mathrm{O}^{+}\right.$and $\left.\mathrm{AB}^{+}\right)$reported by Onyia et al. (2015). The $\mathrm{O}^{-}, \mathrm{A}^{-}$and $\mathrm{B}^{+}$blood groups observed in this study for female cultured C. gariepinus differs from $\left(\mathrm{O}^{+}\right.$and $\left.\mathrm{AB}^{+}\right)$reported by Ayorinde et al. (2009).
The occurrence of two co-dominant genotypes (AA and $\mathrm{BB}$ ) in both wild and cultured strains of C. gariepinus has also been reported in farm animals by Pal and Mummed (2014). Tell (2000) reported that after electrophoresis on cellulose acetate, the $\mathrm{Hb}$ genotype that migrated faster from the point of application at $\mathrm{pH}$ of 8.5-9.0 was labelled AA, the slow-moving fraction was identified as $\mathrm{BB}$ while the heterozygote was $A B$. The results of this study varied with AA genotype reported by Chuku and Uwakwe (2012) for the same fish species and $H$. bidorsalis reported by Onyia et al. (2013). 
A genetic character is known to be polymorphic when the rarest genotype has a frequency greater than one percent (Das and Deb, 2008). Allele B had the highest frequency in both strains followed by allele A. Based on the electrophoretic separation of proteins in the present study, three different alleles, encoding three different genotypes were found on the locus of haemoglobin with higher $\mathrm{B}$, than $\mathrm{A}$ frequency. The AA gene has been reported to confer resistance to helminths on the carriers and the degree of resistance is dose-dependent (FAO, 1988).

The higher $\mathrm{Hb}$ values reported in this study differs from $18.43 \mathrm{~g} / \mathrm{dl}$ and $16.5 \mathrm{~g} / \mathrm{dl}$ reported by (Onyia, 2013). This variation may be due to environmental factors and the size of the fish. According to Lenfant and Johansen (1976) haemoglobin concentration is higher in the fishes capable of aerial respiration. The BD genotype recorded in the wild strain of C. gariepinus caught from Lake Alau indicates incomplete (partial) dominance and is a rare allele. Incomplete (partial) dominance refers to a heterozygous condition in which both alleles at a gene locus are partially expressed, often producing an intermediate phenotype. However, rare alleles according to Underwood (2017) are caused by mutation. The presence of $\mathrm{BD}$ genotype in this population could be an indication of possible natural hybridization.

\section{CONCLUSION}

The wild and cultured populations of C. gariepinus showed genetic variation. The BD genotype observed in the wild population of C. gariepinus caught from Lake Alau indicates incomplete (partial) dominance and rare allele, and could be an indication of natural hybridization.

\section{REFERENCES}

Abubakar, E., Suprijatna and Sutopo. 2014. Genotype Distribution of Local Chicken Crossbred in Poultry Breeding Centre Temanggung-Central Java. International Refereed Journal of Engineering and Science (IRJES). 3(3):01-14.

Adebayo, O. O and Daramola, O. 2013. Economic analysis of catfish Clarias gariepinus production in Ibadan metropolis. Discourse Journal of Agriculture and Food Sciences 1(7): 128-134.
Agaviezor, B. O., Ajayi, F. O. and Benneth, H. N. 2013. Haemoglobin polymorphism in Nigerian indigenous goats in the Niger delta region of Nigeria. International Journal of Science and Nature 1(3):415-419.

Al-Samarrae, S.H. 2006. Potentiality employment of some haematological and biochemical criterions for evaluation of productivity performance traits of Iraqi sheep. Ph.D. Thesis, University of Baghdad.

Anoop, K. R., Sundar K. S., Khan B. A. and Lal, S. 2009. Common Moorhen Gallinula chloropus in the diet of the African catfish Clarias gariepinus, Keoladeo Ghana National Park, India 245pp.

Arora C. L., Acharaya R.M., Kakar S.M. 1971. A note on the association of haemoglobin types with ewe and ram fertility in Indian sheep. Animal Production 13:371-373.

Arora C.L. 1984. Selecting of biochemically polymorphic traits for improving economic traits in Indian sheep. 2. Haemoglobin types. Livestock. Advisers 9:918.

Ayorinde, E.O., Fagbenro, O.A., Offem, B.O. 2009. Haematological characteristics of African bony tongue, Heterotis niloticus (Teleostei:Arapaimidae), in Southwestern Nigeria. Afr J Aqua Sci. 34(1):97101.

Balasubramaniam, P. and Malathi A. 1992. Comparative study of hemoglobin estimated by Drabkin's and Sahli's methods. J. PostgradMed. 38(1):8-9.

Braman, J. C., Stalnaker, C. B., Klar, G. T. and Farley, T. M. 1980. Haemoglobin polymorphism in adult cutthroat trout, Salmo clarkii. Journal of Experimental Zoology 211(3): 411-413

Chineke C. A., Ologun A. G and Ikeobi C. O. N. 2007. Haemoglobin types and production traits in rabbit breeds and crosses. Journal of Biological Sciences 7(1): 210-214.

Chuku, L. C. and Uwakwe, A. A. 2012. Haematological and Biochemical Studies on some Species of Fishes. J. Appl. Sci. Environ. Manage, 16(3):275-278.

Daramandy, E. M. and Daveport, S. G. J. 1985. Haematological Techniques. 2nd Edn. J and A Churchill, London, 167-168. 
Das, A. K. and Deb, R. 2008. Biochemical polymorphism and its relation with some traits of importance in poultry. Veterinary World 1:220-222.

Dally, M. R., Hohenboken, W., Thomas, D. L. and Craig, M. 1980. Relationships between $\mathrm{Hb}$ type and reproduction. Lambs, wool and milk production and health-related traits in crossbred ewes. Journal of Animal Science 50:418-427.

Dimri, C.S. 1978. Studies on Some Polymorphic Systems in Blood of Japanese Quails (Coturnix coturnix japonica). IVRI publisher. 76pp.

Diyaware, M. Y. Haruna, A. B. Abubakar, K. A. and Omitogun, G. O. 2012. Serum protein Electrophoretic characterization of $C$. anguillaris, $\mathrm{H}$. bidorsalis and their hybrids from the Northeast Nigeria. Journal of Microbioliology and Biotechnology Research 2(1):70-77.

Dratch, P.A., Allison A.J., Williams T.L., Kyle B., Wylliee J.G., Littlejohn R.P. 1986. Haemoglobin type and prolificacy in Booroola sheep. Proceedings of New Zealand Society for Animal Production 46:237-240.

Egena, S. S. A. and Alao, R. O. 2014. Haemoglobin polymorphism in selected Farm animalsA Review. Biotechnology in Animal Husbandry 30(3):377-390.

Elmaci, G. 2001. Haemoglobin types in hair goat breeds raised in Bursa region. Ataturk University Ziraatfak. Derg. 32(2):169-171.

Fagbuaro, O., Oso, J. A., Olurotimi, M. B. and Akinyemi, O. 2014. Morphometric and Meristic Characteristics of Clarias gariepinus from Controlled and Uncontrolled. Journal of Agriculture and Ecology Research International2 (1):39-45.

FAO 1988. Laboratory methods for detecting Hemoglobinopaties, Centre for disease control, Atlanta, USA, 45-47.

Fisher, R. A. 1980. The genetical theory of natural selection. Oxford University Press, UK. 7882.

Frydenberg, O., Moller, D., Naevdal, G and Sick, K. 1965. Haemoglobin polymorphism in Norwegian cod populations. Hereditas 53: 257-271.

Garibaldi, L. 1996. List of animal species used in aquaculture. FAO Fisheries Circular,
$91: 173 p$

Google Map. 2017. Lake Alau, Nigeria Geographical Names, map, geographic coordinates.

National Geospatial-Intelligence Agency, Bethesda, MD, USA https:// www.google.com.ng/webhp?sourceid $=\mathrm{c}$ hrome-instant $\&$ rlz $=1$ C 1 CAFA_ enNG672NG691\&ion $=1 \&$ espv $=2 \& i e=$ UTF-8\# $\mathrm{q}=$ Geographical+location +of+Lake+Alau\&*

Laloei, F., Moghim, M., Javanmard, A., Pourkazemi, M. and Panandam, D. K. 2013. Application of microsatellite markers for genetic conservation and management of Persian sturgeon (Acipenser persicus, Borodin, 1897) in the Caspian Sea. Journal of Applied ichthyology 29(4):696-703.

Lee, S.L., Mukherjee T.K., Agamuthu P., Panandam J. M. 1995. Biochemical polymorphism studies of wool-sheep, hair-sheep and their hybrids in Malaysia. Asian Journal of Animal Science 8(4):357364.

Lenfant, C. and Johansen, K. 1976. Gas exchange in gill, skin and lung breathing. Respir. Physiol. 14:211-218.

Lombard, V., Dubreuil, P., Dillman, C and Baril, C. 2001. Genetic distance estimators based on data for plant registration and protection: a review. Acta Horticultura 546:55-63.

Lyklema, J. (1995). Fundamentals of Interface and Colloid Science 2:299-308.

Majolagbe, F. A., Awodiran, M. O. and Awopetu, J. I. 2012. Electrophoretic Studies of (Clarias gariepinus, Burchell 1822) And (Geoffroy Saint-Hilaire 1809) and their Hybrids Ife Journal of Science 141:167-176.

Oghanje E. J, Akpoguma C. D and Ogbijor, J. 2015. Hemoglobin polymorphism in Nigerian indigenous little ruminant population - preparatory examination. International Journal of Animal Breeding and Genetics. 2(4):100-101.

Omitogun, O. G. 2004. Analysis of Swine Genome organisation: Evaluation of Porcine Chromosomal G-T-G Band for physical mapping. Processing of the $29^{\text {th }}$ annual General Conference of the Genetic Society 
of Nigeria. Ariyo, O. J., Ikeobi, C. O. N., Ozoje, M.O., Omitoyin, I. T. and Kehinde, O.B. (Eds.), Held on the 11-14 $4^{\text {th }}$ October, at Abeokuta, Nigeria, 54-57.

Onyia L. U., Michael K. G. and Ekoto, B. 2013. Haematological profile, blood group and genotype of Heterobranchus bidorsalis. Net Journal of Agricultural Science 1(2):69-72.

Onyia, L. U., Diyaware, M. Y., Michael, K. G. Musa, M. and Ochokwu, I. J. 2015. Comparison of Haematological Indices, Blood Group and Genotype of Clarias gariepinus (Burchell, 1822) and Clarias anguillaris (Linneaus, 1758). Journal of Fisheries and Aquatic Science 10: 392-399.

Pal, S.K., Mummed, Y.Y. 2014. Investigation of haemoglobin polymorphism in Ogaden

Cattle. Veterinary World7(4):229-233.

Pante, M. J. R., Lester L.J. and Pullin, R.S.V. 1988. A preliminary analysis on the use of canonical discriminant analysis of morphometric and meristic characters to identify cultured tilapias. In: The Second International Symposium on Tilapia in Aquaculture (Pullin R.S.V., Bhukaswan T., Tonguthai K. and MacClean J.L. (eds.)). ICLARM Conference Proceedings 15, Manila, Philippines, 251-257.

Perez, J. E. and Rylander, M. K. 1985. Hemoglobin heterogeneity in Venezuelan fishes. 209Pp.

Sick, K. 1965. Haemoglobin polymorphism in fishes. Nature, 192:894-896.
Sindermann, C. J. 1967. Blood Types in Fish. The American Biology Teacher 29(6):439-441

Svobodova, Z., Pravda, D. and Palackova, J. 1991. Unified Methods of Haematological Examination of Fish. Research Institute of Fish Culture and Hydrobiology. Vodnany, Czech Republic, 31pp.

Tella, M. A, Taiwo, V. O., Agbede, S. A and Alonge, O. D. 2000. The influence of hemoglobin types of the incidence of babesiosis and anaplasmosis in West African Dwarf and Yankasa sheep. Tropical Veterinary Journal. 18:121 -127.

Torkpo, E. Y., Danquah, E. T., Offei, S. K and Blay, E. T. 2006. Esterase, total protein and seed storage protein diversity in Okra (Abelmochus esculentus L. Moend). West African Journal of Applied Ecology 9:177-183.

Tsunoda, K., Chang, H., Chang, G., Sun, W., Dorji, T., Tsering, G., Yamamoto, Y., Namikawa, T. 2010. Phylogeny of local breeds in East Asia, focusing on the Bayanbulak sheep in China and the Sipsu sheep in Bhutan. Biochemical Genetics 48:1-12.

Underwood, C. (2017). Haemoglobin Electrophoresis, Purposes and Procedure. Health line. Available: http://www.healthline.com/health/hem oglobin-electrophoresis

Yang, N. and Jiang, R. S. (2005). Recent Advances in breeding for chickens. World Poultry Journal. 61:373-381. 